\title{
Trogocytosis in Unicellular Eukaryotes
}

\author{
Kumiko Nakada-Tsukui ${ }^{1, * \mathbb{D}}$ and Tomoyoshi Nozaki ${ }^{2, *(\mathbb{D})}$ \\ 1 Department of Parasitology, National Institute of Infectious Diseases, Tokyo 162-8640, Japan \\ 2 Department of Biomedical Chemistry, Graduate School of Medicine, The University of Tokyo, \\ Tokyo 113-8654, Japan \\ * $\quad$ Correspondence: kumiko@nih.go.jp (K.N.-T.); nozaki@m.u-tokyo.ac.jp (T.N.); Tel.: +81-3-5285-1111 (K.N.-T.); \\ +81-3-5841-3526 (T.N.)
}

check for

updates

Citation: Nakada-Tsukui, K.; Nozaki, T. Trogocytosis in Unicellular Eukaryotes. Cells 2021, 10, 2975 https://doi.org/10.3390/ cells10112975

Academic Editor: Jeremy Simpson

Received: 16 July 2021

Accepted: 17 October 2021

Published: 1 November 2021

Publisher's Note: MDPI stays neutral with regard to jurisdictional claims in published maps and institutional affiliations.

Copyright: (c) 2021 by the authors. Licensee MDPI, Basel, Switzerland. This article is an open access article distributed under the terms and conditions of the Creative Commons Attribution (CC BY) license (https:/ / creativecommons.org/licenses/by/ $4.0 /)$.

\begin{abstract}
Trogocytosis is a mode of internalization of a part of a live cell by nibbling and is mechanistically distinct from phagocytosis, which implies internalization of a whole cell or a particle. Trogocytosis has been demonstrated in a broad range of cell types in multicellular organisms and is also known to be involved in a plethora of functions. In immune cells, trogocytosis is involved in the "cross-dressing" between antigen presenting cells and T cells, and is thus considered to mediate intercellular communication. On the other hand, trogocytosis has also been reported in a variety of unicellular organisms including the protistan (protozoan) parasite Entamoeba histolytica. E. histolytica ingests human $\mathrm{T}$ cell line by trogocytosis and acquires complement resistance and cross-dresses major histocompatibility complex (MHC) class I on the cell surface. Furthermore, trogocytosis and trogocytosis-like phenomena (nibbling of a live cell, not previously described as trogocytosis) have also been reported in other parasitic protists such as Trichomonas, Plasmodium, Toxoplasma, and free-living amoebae. Thus, trogocytosis is conserved in diverse eukaryotic supergroups as a means of intercellular communication. It is depicting the universality of trogocytosis among eukaryotes. In this review, we summarize our current understanding of trogocytosis in unicellular organisms, including the history of its discovery, taxonomical distribution, roles, and molecular mechanisms.
\end{abstract}

Keywords: trogocytosis; phagocytosis; unicellular eukaryotes; Entamoeba histolytica; parasites; cross-dressing; intercellular communication

\section{Introduction}

Phagocytosis is a fundamental cellular process in eukaryotes. It is generally accepted that the last eukaryotic common ancestor emerged by internalization of an $\alpha$ proteobacterium by a phagocytic archaeon, which leads to the mitochondrion, the multifunctional powerhouse of eukaryotes. Furthermore, phagocytosis is believed to be operative in early unicellular eukaryotes as a mechanism for feeding and for defending against predators [1]. Thus, phagocytosis is believed to have played significant roles during the evolution of eukaryotes [2]. In this context, all eukaryotes are, or were, at least some time in evolution, capable of bona fide phagocytosis. However, a majority of cells other than professional phagocytes in multicellular organisms are apparently and presumed to be non-phagocytic. A series of recent studies have revealed that phagocytosis is also present in non-professional phagocytes, and is presumed to play a broader range of roles in multicellular organisms.

While canonical phagocytosis is being demonstrated in a broad range of cell types in multicellular organisms, a new mode of phagocytosis, called trogocytosis, has gained attention. The word "trogo" in Greek means "to nibble" and implies ingestion by piecemeal, which is distinct from phagocytosis, in which a cell internalizes a prey not as pieces, but as a whole without disintegration. Besides morphological differences, the biological role of trogocytosis also seems to be distinct from that of canonical phagocytosis. For instance, trogocytosis has been demonstrated to be involved in a plethora of biological 
functions in multicellular eukaryotes, such as immune modulation, anti-cancer and antipathogen activities, neural homeostasis, embryogenesis, and transmission and propagation of infective agents. In immune cells, trogocytosis is involved in the "cross-dressing" between antigen presenting cells and T cells, and is thus considered to serve for intercellular communication. On the other hand, trogocytosis has been also reported in a variety of unicellular organisms. Trogocytosis has been demonstrated in Entamoeba histolytica, the protistan (protozoan) parasite, which ingests human T cell line by trogocytosis and acquires complement resistance and cross-dresses major histocompatibility complex (MHC) class I on the cell surface. Trogocytosis and trogocytosis-like phenomena (nibbling of a live cell, not previously described as trogocytosis) have been also reported in other parasitic protists such as Trichomonas, Plasmodium, Toxoplasma, and free-living amoebae. Thus, trogocytosis is conserved in diverse eukaryotic supergroups as the means of intercellular communication, thus, depicting the ubiquity among eukaryotes. In this review, we aim to show the ubiquity of trogocytosis in eukaryotes. We summarize our current understanding of trogocytosis in unicellular organisms, including history of discovery, taxonomical distribution, biological roles, and molecular mechanisms of trogocytosis.

\section{Initial Discovery of Cell Nibbling in Unicellular Eukaryotes}

Probably, the first report that described trogocytosis by a unicellular organism was made on a free-living amoeba, Amoeba proteus [3] (Table 1). In this report, A. proteus demonstrated an unusual ingestion behavior: it attached a paramecium, but ingested only half of the pray, leaving the other half uninternalized. Subsequently, it was also reported that $A$. proteus partly ingested the ciliate Frontonia [4] (note that all evidence was provided by illustrations, not photos). Later, fine microscopic images of cell nibbling of a live cell by $A$. proteus and another free-living amoeba, Chaos carolinensis, were documented [5]. Trogocytosis was also demonstrated in the slime mould, Dictyostelium caveatum, which internalized a sibling species Dictyostelium discoideum [6,7]. Since Dictyostelium can also ingest bacteria as prey, internalization of $D$. discoideum by $D$. caveatum was presumed to play a role other than nutrient acquisition. In parallel, Culbertson and colleagues conducted a series of studies on the nibbling behavior of Naegleria fowleri (called N. aerobia then). In their studies, trogocytosis-like events by two species (considered then as two morphologically distinguishable strains of a species) of soil amoebas, N. fowleri HB-1 and HartmannellaAcanthamoeba A-1 [8,9], were described. When those amoebae were inoculated into guinea pigs, it was demonstrated by pathological examination that the amoebae in the thrombi internalized erythrocytes only halfway (i.e., trogocytosis) [9]. Later, trogocytosis of a mouse embryonic cell by $N$. fowleri was also demonstrated by immunofluorescence assay and electron microscopy [10]. In this report, the word "trogocytosis" was used for the first time. Trogocytosis was also described in the enteric parasitic protist, E. histolytica, although the phenomenon regained attention due to presumed contribution to pathogenesis, but had not been referred as trogocytosis [11-15] until recently [16].

Table 1. Trogocytosis by unicellular eukaryotes. List of unicellular protozoa in which trogocytosis or a trogocytosis-like process was demonstrated.

\begin{tabular}{ccccc}
\hline Trogocyte & Life Style & Life Cycle & $\begin{array}{c}\text { Trogocytosis } \\
\text { Target }\end{array}$ & References \\
\hline Amoeba proteus & free-living & trophozoite & $\begin{array}{c}\text { ciliate } \\
\text { (Paramecium, } \\
\text { Frontonia) }\end{array}$ & {$[3,4]$} \\
\hline $\begin{array}{c}\text { Chaos carolinensis } \\
\text { Dictyostelium }\end{array}$ & free-living & trophozoite & $\begin{array}{c}\text { ciliate } \\
\text { (Blapharisma) }\end{array}$ & {$[5]$} \\
\hline
\end{tabular}


Table 1. Cont.

\begin{tabular}{|c|c|c|c|c|}
\hline Trogocyte & Life Style & Life Cycle & $\begin{array}{c}\text { Trogocytosis } \\
\text { Target }\end{array}$ & References \\
\hline Naegleria fowleri & $\begin{array}{c}\text { free- } \\
\text { living/parasititc } \\
\text { (extracellular) }\end{array}$ & trophozoite & mammalian cell & [8-10] \\
\hline $\begin{array}{l}\text { Harmannella- } \\
\text { Acanthamoeba }\end{array}$ & $\begin{array}{c}\text { free- } \\
\text { living/parasititc } \\
\text { (extracellular) }\end{array}$ & trophozoite & mammalian cell & {$[8,9]$} \\
\hline $\begin{array}{l}\text { Entamoeba } \\
\text { histolyca }\end{array}$ & $\begin{array}{l}\text { extracellular } \\
\text { parasite } \\
\text { (intestine) }\end{array}$ & trophozoite & mammalian cell & {$[16,17]$} \\
\hline $\begin{array}{c}\text { Teichomonas } \\
\text { vaginalis }\end{array}$ & $\begin{array}{c}\text { extracellular } \\
\text { parasite } \\
\text { (urogenital tract) }\end{array}$ & trophozoite & mammalian cell & {$[18,19]$} \\
\hline $\begin{array}{l}\text { Plamodium } \\
\text { falciparum }\end{array}$ & $\begin{array}{l}\text { intracellular } \\
\text { parasite } \\
\text { (erythrocyte) }\end{array}$ & $\begin{array}{l}\text { erythtocytic } \\
\text { (trophozoite) }\end{array}$ & $\begin{array}{l}\text { parasitizing } \\
\text { erythrocyte }\end{array}$ & [20-23] \\
\hline Toxoplasma gondii & $\begin{array}{c}\text { intracellular } \\
\text { parasite } \\
\text { (nucleated cells) }\end{array}$ & $\begin{array}{l}\text { tachyzoites; } \\
\text { bardizoites }\end{array}$ & $\begin{array}{l}\text { parasitizing } \\
\text { mammalian cell }\end{array}$ & [24] \\
\hline
\end{tabular}

\section{General Role of Trogocytosis in Eukaryotes}

Several biological roles of trogocytosis have been experimentally demonstrated in unicellular eukaryotes, while other roles were only suggested: feeding/nutrient acquisition, defense/self-protection, pathogenicity, self-nonself discrimination, and intercellular communication. Among these roles, trogocytosis (or trogocytosis-like process) is evidently involved in the three former functions in many protozoa. Also, intercellular communication was demonstrated between E. histolytica and human cells. Self-nonself discrimination was experimentally shown in a Dictyostelium species, however, the molecular mechanism is not fully elucidated.

\subsection{Feeding/Nutrient Acquisition}

The internalized preys can be used as nutrient source in both free-living and parasitic amoebas. Several studies demonstrated degradation of ingested materials [3,4,25-29]. However, a conundrum remains unsolved: what is the advantage of trogocytosis, i.e., partial ingestion of the prey? Possible reasons include thrift: a less amount of membrane (and thus lipids) and energy are used for trogocytosis than phagocytosis. This is quite against intuition because trogocytosis of target cells such as Paramecium, which has firm surface cytoskeleton composed of epiplasmin and actin, and surface cilia connected to the cytoskeleton [30-32], requires high energy and is not energetically economical. It is also of note that apoptotic cells are less elastic than live cells [33]. Another possible advantage of trogocytosis over phagocytosis is that trogocytosis allows selective acquisition of components such as membranes and exclusion of toxic substances such as oxygen and nitrogen radicals in phagosomes from professional phagocytes.

\subsection{Pathogenicity}

Trogocytosis of unicellular organisms has been often studied in the context of pathogenicity. Trogocytosis is involved in pathogenicity and virulence in at least three ways: 1 . direct killing of target cells for cell and tissue damage; 2. elimination of immune cells; 3. generation of niche for symbiosis and parasitism; and 4. acquisition of host molecules for mimicry (see Section 3.4). It has been described in many free-living and parasitic protists such as Naegleria, Hartmannella-Acanthamoeba, and Entamoeba that trogocytosis was clearly implicated in virulence mechanisms $[8,9,13,16]$. The involvement of proteases in the inter- 
section of trogocytosis and pathogenicity was shown in E. histolytica. Trogocytosis of live Jurkat cells by E. histolytica, but not phagocytosis of dead Jurkat cells, was inhibited by a cysteine protease inhibitor E-64 [34]. Trogocytosis of Trichomonas vaginalis trophozoite by a neutrophil was also inhibited by an elastase inhibitor, AEBSF, while the inhibitor did not affect phagocytosis of the dead parasite [35]. In both organisms, proteases are involved in host cell degradation and tissue destruction [36-41]. Furthermore, contribution of proteases to pathogenicity was also demonstrated in Naegleria and Acanthamoeba [42-45]. It needs to be elucidated in those organisms whether protease(s) are also involved in trogocytosis per se. Furthermore, it is necessary to elucidate how proteases are involved in trogocytosis: surface receptor processing, inflammasome formation, and downstream signaling.

\subsection{Self-Nonself Discrimination}

Self-nonself discrimination is often used in the context of immune recognition and immunological tolerance. However, there is also a significant numbers of cases in which the term was used in a broader sense with the representative case being cannibalism between close species of the free-living eukaryotes [46-49]. Trogocytosis has been suggested to play a role in self-nonself discrimination in the social amoeba Dictyostelid species. They are known to generate multicellular fruiting body under starvation conditions. When two different species are mixed, each species is segregated from each other and forms an independent fruiting body. However, in case where D. caveatum was mixed with $D$. discoideum, only the fruiting body of D. caveatum was formed [6] as D. caveatum ingested and killed D. discoideum by trogo- (and phago-) cytosis [6,7]. D. caveatum also trogocytosed themselves, suggesting that self-nonself discrimination mechanisms were selectively lost in this species [50]. The gene involved in self-recognition was identified in Dictyostelid [51,52]. Dictyostelium-specific polymorphic (among D. discoideum strains) transmembrane proteins, TgrB1/TgrC1 (Tgr = Tiger, Transmembrane, IPT, IG, E-set, Repeat protein), serve as a ligand-receptor set unique to each strain [52,53]. Importantly, the TgrB1/TgrC1 system is conserved in a limited group of Dictyostelium species, and neither of the proteins is conserved in D. caveatum [54]. Although further study is necessary to better understand the role of trogocytosis per se in the potential self-nonself discrimination mechanisms, $D$. caveatum is a unique example to understand the role of trogocytosis in kin discrimination. Kin discrimination of Entamoeba was also reported, however, neither responsible genes for self-recognition nor its relationship with trogocytosis has been identified [55].

\subsection{Intercellular Communication}

It has been demonstrated in immune cells that phagocytes receive surface proteins from target cells by trogocytosis, which are subsequently displayed on the surface of the phagocytes. This phenomenon is called cross-dressing and is known in a broad range of cell type pairs including natural killer (NK) cells, basophils, and T cells expressing an artificial chimeric antigen receptor (CAR) (CAR T cells) [17,56-58]. NK cells are known to dress MHC II, which is derived from dendritic cells (DC), and natural killer group 2 membrane D ligand (NKG2DL) from T cell lymphoma cells. As NK cells do not express co-stimulatory molecules necessary for MHC II antigen presentation, the removal of $\mathrm{MHC}$ II from DC and cross-dressing on NK cells causes reduction of the MHC II on DC and suppresses antigen presentation by DC [17]. NKG2DL on T cell lymphoma cell stimulates NKG2D on the NK cell to activate effector activity, leading to killing of T cell lymphoma cells by activated NK cells. NK cells cross-dressing NKG2DL derived from T cell lymphoma cells are killed by other NK cells [56]. This may be considered as one of the escape mechanisms of T cell lymphoma. Basophils were also demonstrated to acquire MHC II from DC by trogocytosis. Basophils then conducts antigen presentation to naïve $\mathrm{CD}^{+} \mathrm{T}$ cells and also provides IL-4 to promote differentiation into Th2 cells [57]. This Th2 reaction is considered to be involved in basophil-mediated allergy. Finally, CAR T cells receive CD19, a B cell antigen, from B cell lymphoma cells by trogocytosis and cross-dress CD19 on CAR T cells [58]. This cross-dressing of CD19 on CAR T cells causes fratricide of CAR 
$\mathrm{T}$ cells and reduction of $\mathrm{CD} 19$ on the B lymphoma cells, which eventually gives rise to tumor relapse. It was demonstrated that E. histolytica acquired complement resistance via trogocytosis of Jurkat $\mathrm{T}$ cells. Importantly, complement resistance was not gained by phagocytosis of dead cells [59]. It has been demonstrated in Plasmodium falciparum, that complement resistance is achieved by acquisition of complement inhibitory molecules CD55 and CD59 on the parasite or infected erythrocytes [60]. This suggests that E. histolytica also acquire CD55 and / or CD59. These molecules are GPI-anchored proteins. It was shown that transfer of GPI-anchored protein appears to occur directly between live cells and via exosomes [61-63]. Contrary, in E. histolytica, it was reported that the transfer of complement resistance depends on actin and direct contact between cells. It was also shown that $E$. histolytica cross-dresses transmembrane domain-containing MHC I, derived from Jurkat cells [59]. These observations may suggest a new paradigm wherein trogocytosis is involved in immune evasion of eukaryotic pathogens [64].

\section{Trogocytosis in Parasitic Protists}

Among unicellular organisms, trogocytosis and trogocytosis-like processes have been recently reported in a wide range of parasitic protists, including E. histolytica, Excavata including Giardia intestinalis, and T. vaginalis and Apicomplexan (Plasmodium falciparum and Toxoplasma gondii) (Table 1). If trogocytosis is a shared common mechanism among eukaryotes, we might find similar cell nibbling behavior in other protists than those so far reported. Among them, trogocytosis in E. histolytica is the best studied, and will be described in a later Section 5.

\subsection{Trichomonas Vaginalis}

T. vaginalis mainly colonizes the vagina and causes one of the most common sexually transmitted diseases worldwide, trichomoniasis [65]. T. vaginalis causes symptoms in humans by its cytopathic effects on host cells, including phago- and trogocytosis, induction of inflammation, and affecting microbiota $[18,66]$. T. vaginalis displays multiple morphologically discernible developmental stages, among which the amoeboid form is capable of phago- and trogocytosis $[19,66]$. It is of note that escape from complement attack is one of the essential immune evasion mechanisms of T. vaginalis $[67,68]$. T. vaginalis acquires CD59 from mouse erythrocytes by cross-dressing [69]. CD59 is a GPI-anchored membrane protein and protects the cell from complement attack by disturbing the formation of membrane attack complex. Although trogocytosis was not described per se, nibbling of live genitourinary epithelial cells by T. vaginalis was demonstrated [70]. It is conceivable that $T$. vaginalis utilizes trogocytosis for immune evasion by cross-dressing CD59 from mouse erythrocytes.

\subsection{Giardia Intestinalis}

Another anaerobic parasitic protist is G. intestinalis, which resides in human and animal small intestines. G. intestinalis was previously believed to internalize extracellular nutrients and essential factors from the extracellular milieu exclusively via fluid-phase and receptor-mediated endocytosis. Thus, it was considered that $G$. intestinalis lacks the capacity to carry out phagocytosis, until it has been recently demonstrated [71]. It was shown that G. intestinalis trophozoite generates pseudopods and forms phagocytic cup and phagosome to internalize bacteria, yeasts, and polystyrene or carboxylated microspheres [71]. It was demonstrated that internalization occurred through the entire cell surface, but, more frequently through the ventral flagella's exit, where clathrin is abundant and receptor mediated endocytosis is operated [72]. Although neither nibbling nor trogocytosis per se was reported, it is conceivable that G. intestinalis is also capable of trogocytosis or trogocytosis-like internalization. Similar to E. histolytica and T. vaginalis, G. intestinalis is also attacked by complement. However, the mechanisms of complement resistance in G. intestinalis remains elusive $[73,74]$. 


\subsection{Trypanosoma and Leishmania}

Trypanosoma and Leishmania belong to the Kinetoplastida in the super group of Excavata, which Trichomonas and Giardia also belong to, and include a number of species that can cause diseases in humans and animals. The Trypanosoma brucei group causes African sleeping sickness in humans and nagana in cattle, while Trypanosoma cruzi causes American trypanosomiasis, Chagas' disease, in humans, and is endemic in Central and South America [75,76]. A complex of Leishmania species is responsible for visceral, cutaneous, and mucocutaneous leishmaniasis in human worldwide [77-79]. It was demonstrated that T. cruzi epimastigotes (the insect stage, living in the insect mid- and hindgut) and amastigotes (the intracellular mammalian stage, living in the host cell cytoplasm) [80-82] display the cytostome-cytopharynx complex, which resembles elongated trogo- and phagosomes. The cytostome-cytopharynx complex is a structure that extends from a position adjacent to the flagellar pocket located at the root of the flagellum, to the distal end in the posterior near the nuclear periphery in the cell. The cytostome-cytopharynx seems to be unique to T. cruzi and has not been demonstrated in either T. brucei or Leishmania $[20,21,83-85]$. In T. brucei and Leishmania, endocytosis exclusively occurs at the flagellar pocket [21,22], whereas in T. cruzi endocytosis occurs at both the flagellar pocket and the cytostome. Since T. cruzi amastigotes reside in the host cell cytoplasm, amastigotes can directly internalize the cytoplasmic components at the flagellar pocket. It was demonstrated that endocytosis at the flagellar pocket is clathrin-dependent, whereas endocytosis at the cytostome is clathrin-independent. However, it remains elusive if T. cruzi amastigotes can ingest the host cell membranes and the membrane-bound organelles (e.g., ER, Golgi, endosomes, and mitochondria) via the cytostome.

\subsection{Plasmodium}

Five Plasmodium species, which belong to the Apicomplexa, cause malaria in humans and are responsible for over 0.45 million mortality annually among mostly children of $<5$ years old in sub-Saharan Africa [86]. Intracellular malaria parasites are segregated from the host cells by two layers of membranes [the parasitophorous vacuole (PV) membrane derived from the host cell and the parasite's plasma membrane] in the host nucleated and anucleated cells. Therefore, malaria parasites are not expected to ingest host components. However, there is a line of evidence suggesting the presence of phago- or trogocytosis-like phenomena. The structure called the cytostome, which was also described in T. cruzi as above, was well documented in the blood (erythrocytic)-stages of P. falciparum, which need to utilize hemoglobin present in the erythrocyte cytosol, for growth $[23,87,88]$. P. falciparum displays the cytostome during an actin-dependent invagination of the erythrocyte cytoplasm into the parasite. The cytostome morphologically resembles the structure that forms during trogocytosis in other organisms and may be considered to be the structure related to a trogocytosis-like process. However, a unique electron-dense ring structure localized at the neck of the cytostomal invagination appears to be unique to Plasmodium, while a narrow tube which connected the cytostome with the food vacuole, called cytopharynx, may be functionally homologous to the tubular bridge found between a mature trogosome and primary (newly formed) trogosome frequently found in E. histolytica. [84,89-92]. Note that the term "trogosome" is defined as the endomembrane endosome-like system formed by trogocytosis, equivalent to the phagosome formed by phagocytosis, but most likely compositionally different from phagosomes and generated in a distinct molecular mechanism from phagosomes. It was shown that the cytostome-cytopharynx is eventually pinched off from the PV membrane and the erythrocyte cytoplasmic content is internalized to be decomposed in the food vacuole [91]. Since partial ingestion of live prey is the definition of trogocytosis, the cytostome-cytopharynx related phenomenon resembles trogocytosis. For instance, a subsequent association of Rab5A and PtdIns3P binding proteins (a FYVE domain containing protein, FCP, and Atg18) with the food vacuole, in the course of cytostome and trogosome formation, and inhibition of cytostome and trogosome formation by a PI3K inhibitor [24,93-95] are shared mechanisms by both of the processes. It has not 
yet been demonstrated that $P$. falciparum is able to cross-dress a protein that originated from the PV membrane.

\subsection{Toxoplasma Gondii}

Toxoplasma gondii, which also belongs to the Apicomplexa, causes toxoplasmosis, the most widespread zoonotic parasitic disease in humans [96]. One-third of the world human population is reported to be infected with T. gondii. T. gondii infection is often presented without serious symptoms in healthy individuals; however in immunocompromised individuals, it potentially leads to lethal encephalitis [97]. Similar to Plasmodium, T. gondii lives in the PV of nucleated cells. The endocytosis-like phenomenon, and a unique cellular structure associated with the phenomenon, the micropore, which is a characteristic electrondense ring structure at the neck of the invagination in tachyzoites and bradyzoites [98], have been well documented. Different from the cytostome of P. falciparum, T. gondii apparently does not internalize the PV membrane by the micropore [98]. This observation was contradicted by recent studies [99-101], in which it has been shown that the micropore can pinch off the PV membrane. Furthermore, it was proposed that $T$. gondii exploits a trogocytosislike pathway to engulf host Rab small GTPases-marked Golgi or Golgi-associated vesicles, which $T$. gondii closely resides to, in order to gain sphingolipids [102,103]. It was further demonstrated that the Golgi-associated vesicles are first sequestered to the intervascular network (IVN), the membrane tubules invaginated from the PV membrane, and subsequently internalized by the parasite [104]. The phenomenon represents one good example of intercellular information exchange in intracellular protozoa. However, it needs to be further validated at the molecular level whether the phenomenon in T. gondii is functionally comparable to trogocytosis or a trogocytosis-like process because the event in T. gondii relies on microtubules but not actin, which is different from trogocytosis in other organisms.

\section{Molecular Mechanisms of Trogocytosis in E. histolytica}

Among unicellular eukaryotes, trogocytosis have been best studied in E. histolytica at the molecular level $[16,29,34,105,106]$. Proteins and lipids involved in trogocytosis are largely conserved between human and E. histolytica. So far, only one protein, AGC kinase 1 (AGCK1) from E. histolytica, clearly differentiates trogocytosis and phagocytosis [105,107]. However, a series of events that exclusively and selectively occur in trogocytosis, but not in phagocytosis, and the underlying mechanisms, need to be demonstrated to better understand the physiological significance of trogocytosis. In this part, we divided the sequential events that occur in trogocytosis into 6 major phases: (1) target recognition via a receptor on the plasma membrane, (2) triggering of phosphatidylinositol (PtdIns) and calcium signaling on the plasma membrane; (3) recruitment of effectors; (4) actin rearrangement leading to eventual internalization of the target; (5) closure of the trogosome; and (6) acidification and maturation of the trogosome. We summarized below the current knowledge on the key events that occur during trogocytosis in E. histolytica (Figure 1 and Table 2). Although we assume that a majority of the events are common for trogocytosis and phagocytosis, this assumption needs to be experimentally proven in future (Table 2). 


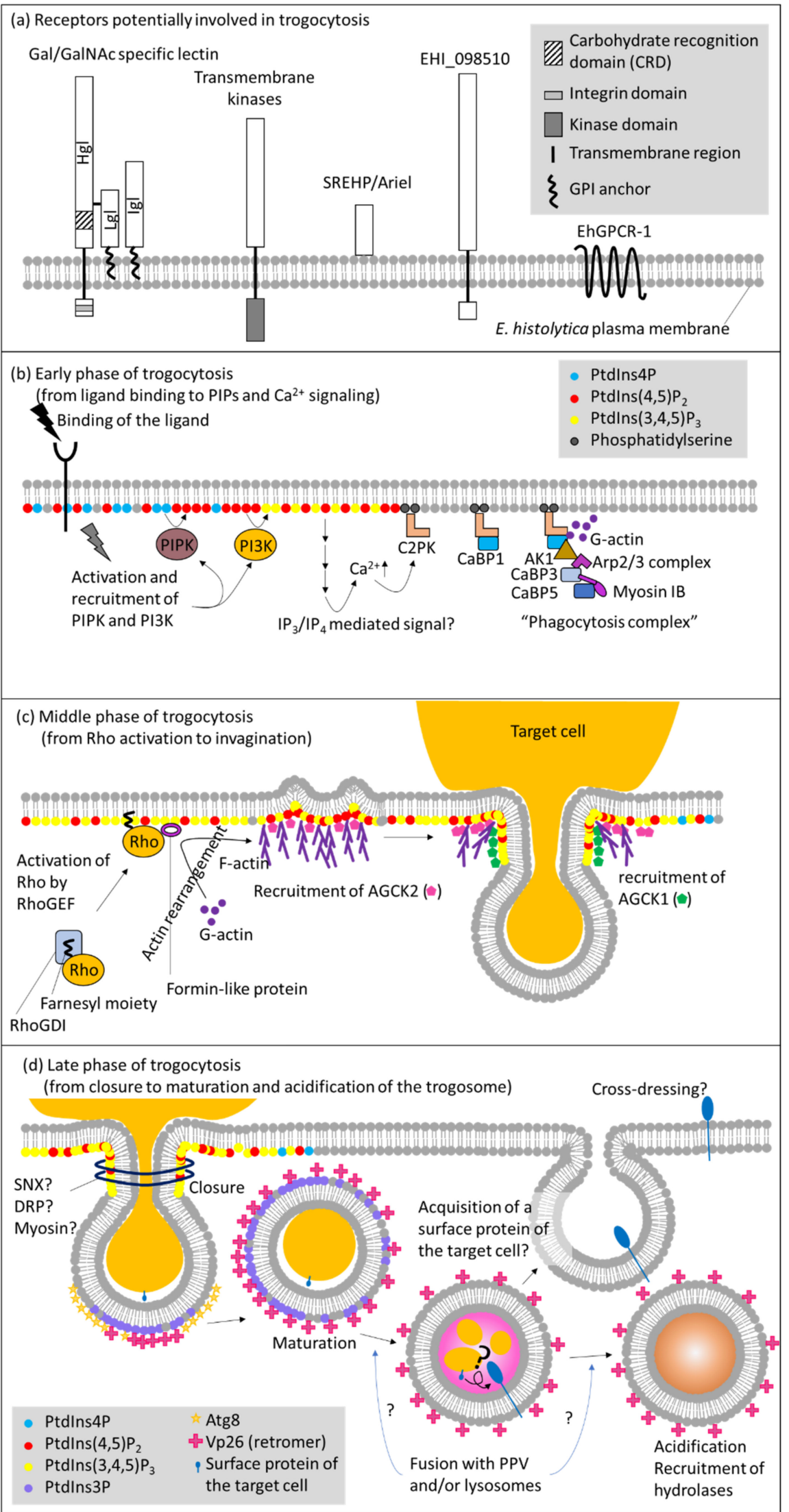

Figure 1. Molecular mechanisms of trogocytosis in E. histolytica. Schematic representation of molecules known or predicted to be involved in trogocytosis in E. histolytica. (a) Receptors that are presumed to 
be involved in the initiation of trogocytosis, by analogy to phagocytosis. A series of major events and molecules involved at each step during the (b) early(from ligand binding to PIPs and $\mathrm{Ca}^{2+}$ signaling), (c) middle (from Rho activation to invagination), and (d) late (from closure to maturation and acidification of the trogosome) phases of trogocytosis, respectively. Abbreviations: AK, atypical kinase; Arp2/3 complex, actin related protein 2/3 complex; $\mathrm{C} 2 \mathrm{PK}, \mathrm{C} 2$ domain-containing protein kinase; CaBP, calcium binding protein; DRP, dynamin-related protein; GPCR, G protein-coupled receptor; GPI, glycosylphosphatidylinositol; IP3, inositol trisphosphate; IP4, inositol tetrakisphosphate; PI3K, phosphatidylinositol 3-kinase; PIPK, phosphatidylinositol phosphate kinase; PPV, prephagosomal vacuole; PtdIns, phosphatidylinositol; RhoGDI, Rho guanine nucleotide dissociation inhibitor; RhoGEF, Rho guanine nucleotide exchange factor; SNX, sorting nexin; SREHP, serine rich Entamoeba histolytica protein.

Table 2. Proteins involved in trogocytosis and phagocytosis in E. histolytica. See Figure 1 for details.

\begin{tabular}{|c|c|c|c|}
\hline Category & Molecules & Trogocytosis & Phagocytosis \\
\hline Adherence & Surface Molecules & Gal lectin & $\begin{array}{c}\text { Gal lectin } \\
\text { Transmembranare kinases } \\
\text { SREHP/Ariel } \\
\text { EHI_098510 } \\
\text { EhGPCR-1 }\end{array}$ \\
\hline \multirow{3}{*}{ Signaling } & Phosphatidylinositol kinases & PI3K & $\begin{array}{l}\text { PIPKI } \\
\text { PI3K }\end{array}$ \\
\hline & Protein kinases & $\begin{array}{c}\text { C2PK } \\
\text { AGCK1 } \\
\text { AGCK2 }\end{array}$ & $\begin{array}{c}\text { C2PK } \\
\text { AGCK2 } \\
\text { AK1 }\end{array}$ \\
\hline & Calcium binding proteins & Unknown & $\mathrm{CaBP} 1 / 3 / 5$ \\
\hline Formation & $\begin{array}{l}\text { Cytoskeletal proteins and } \\
\text { regulators }\end{array}$ & actin & $\begin{array}{c}\text { Actin } \\
\text { Formin } \\
\text { Arp2/3 complex } \\
\text { EhRho1 } \\
\text { EhRacA }\end{array}$ \\
\hline Closure & $\begin{array}{c}\text { Cytoskeletal proteins and } \\
\text { regulators }\end{array}$ & Unknown & Myosin IB \\
\hline Maturation & $\begin{array}{l}\text { Phospholipids, vesicular } \\
\text { traffic-related proteins }\end{array}$ & $\begin{array}{c}\text { PtdIns3P } \\
\text { Vps26 (retromer) } \\
\text { Atg8 }\end{array}$ & $\begin{array}{c}\text { PtdIns3P } \\
\text { Vps26 (retromer) } \\
\text { Atg8 }\end{array}$ \\
\hline
\end{tabular}

\subsection{Receptors and Downstream Signaling}

Trogocytosis and phagocytosis are induced by ligand-receptor binding. In model organisms, a variety of ligand-receptor systems involved in direct recognition of pathogens are known, including pathogen-associated molecular patterns (PAMPs) and pattern-recognition receptors (PRRs). It was well established that PRRs such as Dectin-1, Mincle, MCL, and DC-SIGN trigger phagocytosis [108]. Alternatively, pathogens are first decorated with immunoglobulins or complement C3bi and subsequently recognized by Fc- $\gamma$ and CR3 receptor, respectively [109]. Apoptotic cells are also directly or indirectly (via phosphatidylserinebinding proteins) recognized by receptors for externalized phosphatidylserine [110]. In E. histolytica, surface receptors had been previously identified before the concept of trogocytosis regained attention. Thus, in a strict sense, most of the receptors were demonstrated to be involved in phagocytosis, but not trogocytosis per se. Such receptors include transmembrane kinases (TMKs) [TMKB3-96 (PATMK), TMKC-39, and TMKB1-9], serine rich Entamoeba histolytica protein (SREHP)/Ariel, EHI_098501, and G protein-coupled receptor (EhGPCR1) [111,112] (Figure 1a).

It was demonstrated that Gal/GalNAc-specific lectin (Gal lectin), composed of the transmembrane domain-containing heavy subunit and the GPI-anchored light and inter- 
mediate subunits, is involved in trogocytosis using a specific antibody against the heavy subunit [16]. However, Gal lectin is not specifically involved in trogocytosis, but also phagocytosis. Gal lectin is involved in the adhesion to bacteria, erythrocytes, live $\mathrm{CHO}$ cells, live and dead Jurkat cells, and mucin [16,113-119]. However, downstream signaling directly elicited by the binding of a ligand to Gal/GalNAc specific lectin is not well understood. The integrin-like domain in the 41 a.a.-long cytoplasmic region of the heavy subunit is assumed to play a role in inside-out signaling and adherence to the target [120]. Besides, neither recognizable domains nor potential binding proteins have been identified for the lectin, leaving no clue for downstream signaling events [121-123]. It was shown that expression of GFP fused to the transmembrane domain and the C-terminal cytoplasmic region of the heavy subunit caused dominant negative effect on the adhesion to $\mathrm{CHO}$ cells, and liver abscess formation in the animal model. However, ingestion of erythrocytes, complement resistance, and cytolysis toward mammalian cells were unaffected [120], which were counter-intuitive, but maybe indicative of attachment and downstream events occur independently. Involvement of TMKs, SREHP/Ariel, EHI_098501, and EhGPCR1 in trogocytosis is not demonstrated, while they were shown to be engaged in phagocytosis of erythrocytes, mammalian cells, and bacteria [111,112].

We recently identified a potential trogocytosis-specific isotype of the heavy subunit of the lectin. This protein is apparently involved in the trogocytosis of fresh human erythrocytes, and, to a lesser extent, phagocytosis of aged or damaged erythrocytes (unpublished).

\subsection{Phosphatidylinositol, Calcium Signaling, and Protein Kinases}

The role of phospholipids and calcium signaling on the plasma membrane in trogocytosis and phagocytosis has been well documented [16,105,124-126]. Wortmannin, a phosphatidylinositol 3-kinase (PI3K) inhibitor was shown to inhibit trogocytosis and phagocytosis $[16,124,127]$ (Figure 1b).

Neither the compartment of $\mathrm{Ca}^{2+}$ storage nor the mechanisms for $\mathrm{Ca}^{2+}$ release in E. histolytica has been clearly demonstrated. However, it was shown that inositol 1,4,5trisphosphate $\left(\mathrm{IP}_{3}\right)$ and inositol 1,3,4,5-tetrakisphosphate $\left(\mathrm{IP}_{4}\right)$ likely regulate $\mathrm{Ca}^{2+}$ mobilization $[128,129]$. These second messengers are generally generated from phosphatidylinositol 4,5-bisphosphate $\left[\operatorname{PtdIns}(4,5) \mathrm{P}_{2}\right]$ by the action of phospholipase C (PLC), although homologues for PLC and $\mathrm{IP}_{3}$ receptor are lacking in E. histolytica [125,129]. It may be possible that an unknown phospholipase other than PLC cleaves PtdIns $(4,5) \mathrm{P}_{2}$, or an alternative pathway exists to generate $\mathrm{IP}_{3}$ and $\mathrm{IP}_{4}$ like what was reported in Dictyostelium [130]. The absence of predictable orthologs for $\mathrm{IP}_{3}$ receptor is observed in several protozoa, and is currently attributed to the low levels of conservation at the primary sequences, as shown in Trypanosoma cruzi $[131,132]$. Later, it has been shown that Dictyostelium has an alternative pathway to generate $\mathrm{IP}_{3}$ from $\operatorname{Ins}(1,3,4,5,6) \mathrm{P}_{5}$ [133]. $\mathrm{C} 2$ domain containing protein kinase a calcium-binding protein, $\mathrm{C} 2 \mathrm{PK}$, is translocated to the plasma membrane and binds to phosphatidylserine in a $\mathrm{Ca}^{2+}$ dependent manner [124]. C2PK subsequently recruits $\mathrm{Ca}^{2+}$ binding protein 1 (CaBP1) and other effectors including CaBP3, CaBP5, atypical kinase 1 (AK1), Arp2/3 complex, and myosin IB, which consist the "phagocytosis complex" [124,126,134]. Since both C2PK and CaBP1 are actin-binding proteins [124], calcium signaling plays a pivotal role in actin dynamics during trogocytosis and phagocytosis. The involvement of $\mathrm{C} 2 \mathrm{PK}$ in trogocytosis has been shown: expression of kinase dead C2PK caused defect in trogocytosis and phagocytosis. It is conceivable to speculate a possibility that the components of the phagocytosis complex may vary between trogocytosis and phagocytosis.

Among a number of phosphatidylinositol 3,4,5-trisphosphate $\left[\operatorname{Ptd} \operatorname{Ins}(3,4,5) \mathrm{P}_{3}\right]$ binding proteins, AGCK1 was shown to be exclusively involved in trogocytosis $[105,135]$ (Figure 1c). AGCK1 and another isotype of AGCK, AGCK2, were identified by affinity pull down using PtdIns $(3,4,5) \mathrm{P}_{3}$-immobilized beads in our attempt to isolate PtdIns $(3,4,5) \mathrm{P}_{3}$ binding proteins [105]. It was clearly demonstrated that AGCK1 was exclusively involved in trogocytosis, but not phagocytosis, by reverse genetic studies in which expression of AGCK1 or AGCK2 was specifically repressed by small antisense RNA-medicated tran- 
scriptional gene silencing, or when kinase dead mutants were expressed. In contrast to the specific role of AGCK1 in trogocytosis, AGCK2 was shown to be involved in a broad range of endocytic processes including fluid-phase endocytosis, trogocytosis, and phagocytosis. AGCK1 and AGCK2 also showed distinct recruitment and localization profiles during trogocytosis. Prior to trogocytosis, AGCK2 was localized at the attachment site of the plasma membrane. Upon initiation of trogocytosis, AGCK2 was concentrated at the invagination site in the plasma membrane proximal region. At the same time, AGCK1 was localized at the tunnel structure that connected the partially ingested target cell and the newly formed (not yet enclosed) trogosome (called the trogocytic tunnel). Generation of the trogocytic tunnel structure appears to be the key event of trogocytosis. AGCKs are generally activated downstream of class I PI3K [136]. The E. histolytica genome encodes 24 AGCKs and 6 class I PI3Ks [125,137,138]. It is important in future studies to determine whether other AGCKs are also specifically or universally involved in trogocytosis and phagocytosis, and which class I PI3Ks activate such AGCKs. Furthermore, two Rho guanine nucleotide exchange factor (RhoGEFs) and one formin domain containing protein were identified as PtdIns $(3,4,5) \mathrm{P}_{3}$ binding proteins [135], which also reinforces the notion that PtdIns $(3,4,5) \mathrm{P}_{3}$ is involved in cytoskeleton reorganization (see below).

\subsection{Cytoskeletal Reorganization via Rho Small GTPases}

Rho small GTPases are known to play a pivotal role in actin cytoskeleton reorganization (Figure 1c) and may be key players to differentiate trogocytosis and phagocytosis. In model organisms, it is known that three representative Rhos - RhoA, Rac, Cdc42, and RhoGEF, which is activated via receptor signaling, are involved in the formation of stress fiber, lamellipodia, and filopodia [139,140]. Lamellipodia formation is associated with and is necessary for trogocytosis and phagocytosis. In human macrophages, it was demonstrated that activation of RhoA, instead of Rac, enhanced nibbling (trogocytosis) and reduced removal of necroptotic cells [141]. E. histolytica possesses 19 Rho small GTPases. Although there are only limited studies on each Rho available, specific roles of some isotypes were demonstrated. For example, EhRacA is involved in phagocytosis of erythrocytes, but not in fluid phase endocytosis [127], whereas EhRacG is involved in cytokinesis and uroid formation [142]. EhRho1 contributes to phagocytosis and formation of membrane blebs $[143,144]$. Thus, it is conceivable that specific Rhos are differentially involved in trogocytosis and phagocytosis in E. histolytica.

\subsection{Closure of Trogosomes}

To complete internalization of the prey, sealing of the trogocytic cup and pinching-off of the newly formed trogosome is needed (Figure 1d). Generally, dynamin or BAR domaincontaining sorting nexin (SNX) is responsible in pinching-off of the plasma membrane invagination. Dynamin-1 and LST4 (SNX9) were demonstrated during trogocytosis in C. elegans [145]. E. histolytica possesses 4 dynamin-related proteins (Drps), two of which are in the cytosol while the other two are in the nucleus [146]. While these two cytosolic Drps are involved in mitosome fission, they may also be involved in trogosome pinch-off. E. histolytica also possesses 30 BAR domain proteins. However, no SNX protein with dual BAR and PX domains is present [29], leaving a potential involvement of BAR domain proteins in trogosome formation an open question. It was previously shown that myosins are involved in the closure of the phagosome in macrophages [147]. E. histolytica has a single myosin, myosin IB, and its role in cooperation with $\mathrm{CaBP} 3$ in phagosome closure was demonstrated [148]. In phagocytosis, CaBP1 recruits AK1, which further recruits Arp2/3 complex. The Arp2/3 complex binds to CaBP3, which is a myosin IB binding protein, in a $\mathrm{Ca}^{2+}$ dependent manner. This series of events localizes myosin IB and CaBP3 at the site of phagosome closure [148]. Thus, it is plausible that CaBP3 and myosin IB also play a similar role in trogocytosis [148]. 


\subsection{Maturation of Trogosomes vs. Phagosomes}

It is not well understood if molecules involved in the maturation of the trogosome differ from those in phagosome maturation. Several key molecules are apparently shared in both trogocytosis and phagocytosis, such as Vps26 (retromer), Atg8, and PtdIns3P [28,29,149,150] (Figure 1d). It is worth noting that the prephagosomal vacuole (PPV) may be more closely associated with phagocytosis than trogocytosis. PPV was first identified as a large vacuolar compartment that emerged upon ingestion of human erythrocytes [26]. PPV contains various hydrolases and fuses with the primary phagosome to deliver digestive proteins [26] PPVs were more frequently observed when E. histolytica trophozoites were incubated with dead mammalian cells to allow phagocytosis than when incubated with live cells (NakadaTsukui, unpublished observation). However, the precise role of PPV in phagocytosis remains undetermined. Cross-dressing between immune cells, described above, is observed only when a live target cell is ingested by the recipient cell via trogocytosis $[17,56-58]$. During trogocytosis and cross presentation, membrane proteins that have been derived from the host cell plasma membrane via trogocytosis, need to retain integrity and topology to be properly cross presented on the recipient's plasma membrane. In contrast, the content of phagosomes cannot be selectively degraded. Thus, it is conceivable that the maturation process differ between trogosomes and phagosomes.

It has been well established that a panel of hydrolases including proteases, peptidases, and glycosidases are recruited to phagosomes [151-154]. However, it remains to be determined if these hydrolases are specifically recruited to trogosomes vs. phagosomes. In accordance with the premise mentioned above, it is probably so. It has been recently shown that trogocytosis, but not phagocytosis, was inhibited by a cysteine protease inhibitor [34]. A similar observation was demonstrated in neutrophils, in which an elastase inhibitor selectively inhibits trogocytosis [35]. It is not well understood how proteases are involved in trogocytosis, other than degradation of ingested substances, and why inhibition of protease activity selectively represses trogocytosis. Proteases may be involved in the deformation of the prey, which is needed for trogocytosis.

\subsection{Physiological Role of Trogocytosis in E. histolytica}

E. histolytica exploits trogocytosis for multiple purposes. First, E. histolytica uses trogocytosis for nutrients, presumably membrane lipids, from the host cells and other eukaryotic prey. The advantages of trogocytosis for nutrient acquisition are described above (see Section 3.1). Second, E. histolytica acquires complement resistance via trogocytosis, which was demonstrated in an experiment using Jurkat $T$ cells. Complement resistance was not gained by phagocytosis of dead cells [59]. Although the molecule responsible for the transfer of complement resistance remains unknown, dressing of MHC I, CD59 or another complement inhibitory molecule is likely responsible for this phenomenon. In this context, trogocytosis is integrated in parasitism, immune evasion, and pathogenesis. Finally, although it remains unclear if trogocytosis is a measure of self-nonself discrimination, the topic seems worth pursuing.

\section{Conclusions and Future Perspective}

As summarized in this review, trogocytosis is a widely conserved mechanism in eukaryotes including free-living and parasitic protists. It is likely that trogocytosis will be demonstrated in a broader range of eukaryotes and the functional diversity of trogocytosis other than nutrient acquisition, pathogenicity, immunity, self-nonself discrimination, and immune evasion, shall be demonstrated in life. The link between trogocytosis and selfnonself discrimination discovered in free-living and parasitic eukaryotes has led us to a key question: "what is the self?". If trogocytosis and cross-dressing modifies the self without a trace of change in the genome, the diversity of life on Earth, in the context we currently understand through genetic information, is largely underestimated. Furthermore, as trogocytosis and cross-dressing widens the spectrum and increases the flexibility of the 
self, organism-organism relationship, which also includes host-pathogen interactions, are also largely affected by the trogocytosis-associated phenomena.

Although comparative genomics and proteomics are powerful tools to elucidate molecular mechanisms of the ubiquitous core units of biological processes, central components of phagocytosis ubiquitous in eukaryotes have not been identified with an exception of actin, by phagosome proteomics of 5 eukaryotic organisms [155]. This important observation indicates that the molecular evolution of trogocytosis cannot be elucidated only by multitaxa comparison of orthologous genes known to be involved in trogocytosis. Such presumption prompts us to investigate lineage-specific molecular mechanisms of trogocytosis in each system based on the shared morphological and molecular annotation/definition of trogocytosis. Once trogocytosis is demonstrated and mechanistically characterized in a broader range of unicellular organisms including free-living protists, trogocytosis may gain full attention as a ubiquitous mechanism to acquire molecules and associated information from other organisms in the environment. Such paradigm shift has tremendous impact on our understanding of eukaryote evolution.

Author Contributions: Conceptualization, K.N.-T., T.N.; writing-original draft preparation, K.N.T.; writing—review and editing, K.N.-T., T.N.; visualization, K.N.-T.; supervision, T.N.; project administration, K.N.-T.; funding acquisition, K.N.-T., T.N. All authors have read and agreed to the published version of the manuscript.

Funding: This research was funded by Grants-in-Aid for Scientific Research (B) (KAKENHI JP18H02650 and JP21H02723 to T.N.), Scientific Research (B) and Scientific Research on Innovative Areas (JP19H03463 and JP20H05353 to K.N-T.) from Ministry of Education, Culture, Sports, Science and Technology (MEXT) or Japan Society for Promotion of Sciences (JSPS), Grant for re-search on emerging and re-emerging infectious diseases from Japan Agency for Medical Research and Development (AMED, JP20fk0108138 to T.N.; JP20fk0108139 to K.N-T.), Grant for Science and Technology Research Partnership for Sustainable Development (SATREPS) from AMED and Japan International Cooperation Agency (JICA) (JP20jm0110022 to T.N.).

Conflicts of Interest: The authors declare no conflict of interest.

\section{References}

1. Cavalier-Smith, T. The Phagotrophic Origin of Eukaryotes and Phylogenetic Classification of Protozoa. Int. J. Syst. Evol. Microbiol. 2002, 52, 297-354. [CrossRef]

2. Cavalier-Smith, T. Predation and Eukaryote Cell Origins: A Coevolutionary Perspective. Int. J. Biochem. Cell Biol. 2009, 41, 307-322. [CrossRef] [PubMed]

3. Mast, S.O.; Root, F.M. Observations on Ameba Feeding on Infusoria, and Their Bearing on the Surface-Tension Theory. Proc. Natl. Acad. Sci. USA 1916, 2, 188-189. [CrossRef] [PubMed]

4. Beers, C.D. Observations on Amoeba Feeding on the Ciliate Frontonia. J. Exp. Biol. 1924, 1, 335. [CrossRef]

5. Jeon, K.W.; Jeon, M.S. Generation of Mechanical Forces in Phagocytosing Amoebae: Light and Electron Microscopic Study 1. J. Protozool. 1983, 30, 536-538. [CrossRef]

6. Waddell, D.R. A Predatory Slime Mould. Nature 1982, 298, 464-466. [CrossRef]

7. Waddell, D.R.; Vogel, G. Phagocytic Behavior of the Predatory Slime Mold, Dictyostelium caveatum. Exp. Cell Res. 1985, 159, 323-334. [CrossRef]

8. Culbertson, C.G. Pathogenic Naegleria and Hartmannella (Acanthamoeba). Ann. N.Y. Acad. Sci. 1970, 174, 1018-1022. [CrossRef] [PubMed]

9. Culbertson, C.G. The Pathogenicity of Soil Amebas. Annu. Rev. Microbiol. 1971, 25, 231-254. [CrossRef]

10. Brown, T. Observations by Immunofluorescence Microscopy and Electron Microscopy on the Cytopathogenicity of Naegleria fowleri in Mouse Embryo-Cell Cultures. J. Med. Microbiol. 1979, 12, 363-371. [CrossRef] [PubMed]

11. Councilman, W.T.; LaFleur, H.A. Amoebic Dysentery. Johns Hopkins Hosp. Rep. 1891, 2, 395.

12. Orozco, E.; Guarneros, G.; Martinez-Palomo, A.; Sánchez, T. Entamoeba histolytica. Phagocytosis as a Virulence Factor. J. Exp. Med. 1983, 158, 1511-1521. [CrossRef] [PubMed]

13. Martinez-Palomo, A.; Gonzalez-Robles, A.; Chavez, B.; Orozco, E.; Fernandez-Castelo, S.; Cervantes, A. Structural Bases of the Cytolytic Mechanisms of Entamoeba histolytica. J. Protozool. 1985, 32, 166-175. [CrossRef] [PubMed]

14. Martinez-Palomo, A.; da Silva, P.P.; Chavez, B. Membrane Structure of Entamoeba histolytica: Fine Structure of Freeze-Fractured Membranes. J. Ultrastruct. Res. 1976, 54, 148-158. [CrossRef]

15. Lejeune, A.; Gicquaud, C. Evidence for Two Mechanisms of Human Erythrocyte Endocytosis by Entamoeba histolytica-like Amoebae (Laredo Strain). Biol. Cell 1987, 59, 239-245. [CrossRef] [PubMed] 
16. Ralston, K.S.; Solga, M.D.; Mackey-Lawrence, N.M.; Somlata, N.; Bhattacharya, A.; Petri, W.A. Trogocytosis by Entamoeba histolytica Contributes to Cell Killing and Tissue Invasion. Nature 2014, 508, 526-530. [CrossRef] [PubMed]

17. Nakayama, M.; Takeda, K.; Kawano, M.; Takai, T.; Ishii, N.; Ogasawara, K. Natural Killer (NK)-Dendritic Cell Interactions Generate MHC Class II-Dressed NK Cells That Regulate CD4+ T Cells. Proc. Natl. Acad. Sci. USA 2011, 108, 18360-18365. [CrossRef]

18. Mercer, F.; Johnson, P.J. Trichomonas vaginalis: Pathogenesis, Symbiont Interactions, and Host Cell Immune Responses. Trends Parasitol. 2018, 34, 683-693. [CrossRef] [PubMed]

19. Pereira-Neves, A.; Benchimol, M. Phagocytosis by Trichomonas vaginalis: New Insights. Biol. Cell 2007, 99, 87-101. [CrossRef]

20. Weinman, D.; White, E.A.; Antipa, G.A. Trypanosoma lucknowi, a New Species of Trypanosome from Macaca mulatta with Observations on Its Fine Structure. J. Protozool. 1984, 31, 429-433. [CrossRef] [PubMed]

21. Halliday, C.; Billington, K.; Wang, Z.; Madden, R.; Dean, S.; Sunter, J.D.; Wheeler, R.J. Cellular Landmarks of Trypanosoma brucei and Leishmania mexicana. Mol. Biochem. Parasitol. 2019, 230, 24-36. [CrossRef] [PubMed]

22. Halliday, C.; de Castro-Neto, A.; Alcantara, C.L.; Cunha-E.-Silva, N.L.; Vaughan, S.; Sunter, J.D. Trypanosomatid Flagellar Pocket from Structure to Function. Trends Parasitol. 2021, 37, 317-329. [CrossRef] [PubMed]

23. Rudzinska, M.A.; Trager, W.; Bray, R.S. Pinocytotic Uptake and the Digestion of Hemoglobin in Malaria Parasites. J. Protozool. 1965, 12, 563-576. [CrossRef]

24. Dalal, S.; Klemba, M. Amino Acid Efflux by Asexual Blood-Stage Plasmodium falciparum and Its Utility in Interrogating the Kinetics of Hemoglobin Endocytosis and Catabolism in Vivo. Mol. Biochem. Parasitol. 2015, 201, 116-122. [CrossRef] [PubMed]

25. Mitra, B.N.; Yasuda, T.; Kobayashi, S.; Saito-Nakano, Y.; Nozaki, T. Differences in Morphology of Phagosomes and Kinetics of Acidification and Degradation in Phagosomes between the Pathogenic Entamoeba histolytica and the Non-Pathogenic Entamoeba dispar. Cell Motil. Cytoskelet. 2005, 62, 84-99. [CrossRef] [PubMed]

26. Saito-Nakano, Y.; Yasuda, T.; Nakada-Tsukui, K.; Leippe, M.; Nozaki, T. Rab5-Associated Vacuoles Play a Unique Role in Phagocytosis of the Enteric Protozoan Parasite Entamoeba histolytica. J. Biol. Chem. 2004, 279, 49497-49507. [CrossRef] [PubMed]

27. Mitra, B.N.; Kobayashi, S.; Saito-Nakano, Y.; Nozaki, T. Entamoeba histolytica: Differences in Phagosome Acidification and Degradation between Attenuated and Virulent Strains. Exp. Parasitol. 2006, 114, 57-61. [CrossRef]

28. Picazarri, K.; Nakada-Tsukui, K.; Tsuboi, K.; Miyamoto, E.; Watanabe, N.; Kawakami, E.; Nozaki, T. Atg8 Is Involved in Endosomal and Phagosomal Acidification in the Parasitic Protist Entamoeba histolytica. Cell Microbiol. 2015, 17, 1510-1522. [CrossRef] [PubMed]

29. Watanabe, N.; Nakada-Tsukui, K.; Nozaki, T. Two Isotypes of Phosphatidylinositol 3-Phosphate-Binding Sorting Nexins Play Distinct Roles in Trogocytosis in Entamoeba histolytica. Cell Microbiol. 2020, 22, e13144. [CrossRef] [PubMed]

30. Campillo, C.; Jerber, J.; Fisch, C.; Simoes-Betbeder, M.; Dupuis-Williams, P.; Nassoy, P.; Sykes, C. Mechanics of MembraneCytoskeleton Attachment In Paramecium. New, J. Phys. 2012, 14, 125016. [CrossRef]

31. Pomel, S.; Diogon, M.; Bouchard, P.; Pradel, L.; Ravet, V.; Coffe, G.; Viguès, B. The Membrane Skeleton in Paramecium: Molecular Characterization of a Novel Epiplasmin Family and Preliminary GFP Expression Results. Protist 2006, 157, 61-75. [CrossRef] [PubMed]

32. Kissmehl, R.; Sehring, I.M.; Wagner, E.; Plattner, H. Immunolocalization of Actin in Paramecium Cells. J. Histochem. Cytochem. 2004, 52, 1543-1559. [CrossRef] [PubMed]

33. Vorselen, D.; Labitigan, R.L.D.; Theriot, J.A. A Mechanical Perspective on Phagocytic Cup Formation. Curr. Opin. Cell Biol. 2020, 66, 112-122. [CrossRef]

34. Gilmartin, A.A.; Ralston, K.S.; Petri, W.A. Inhibition of Amebic Cysteine Proteases Blocks Amebic Trogocytosis but Not Phagocytosis. J. Infect. Dis. 2020, 221, 1734-1739. [CrossRef] [PubMed]

35. Mercer, F.; Ng, S.H.; Brown, T.M.; Boatman, G.; Johnson, P.J. Neutrophils Kill the Parasite Trichomonas vaginalis Using Trogocytosis. PLoS Biol. 2018, 16, e2003885. [CrossRef]

36. Weiss, S.J. Tissue Destruction by Neutrophils. N. Engl. J. Med. 1989, 320, 365-376. [CrossRef] [PubMed]

37. Taggart, C.C.; Greene, C.M.; Carroll, T.P.; O’Neill, S.J.; McElvaney, N.G. Elastolytic Proteases: Inflammation Resolution and Dysregulation in Chronic Infective Lung Disease. Am. J. Respir. Crit. Care Med. 2005, 171, 1070-1076. [CrossRef] [PubMed]

38. Liu, H.; Lessieur, E.M.; Saadane, A.; Lindstrom, S.I.; Taylor, P.R.; Kern, T.S. Neutrophil Elastase Contributes to the Pathological Vascular Permeability Characteristic of Diabetic Retinopathy. Diabetologia 2019, 62, 2365-2374. [CrossRef] [PubMed]

39. Hellberg, A.; Nickel, R.; Lotter, H.; Tannich, E.; Bruchhaus, I. Overexpression of Cysteine Proteinase 2 in Entamoeba histolytica or Entamoeba dispar Increases Amoeba-Induced Monolayer Destruction in Vitro but Does Not Augment Amoebic Liver Abscess Formation in Gerbils. Cell Microbiol. 2001, 3, 13-20. [CrossRef] [PubMed]

40. Thibeaux, R.; Dufour, A.; Roux, P.; Bernier, M.; Baglin, A.-C.; Frileux, P.; Olivo-Marin, J.C.; Guillén, N.; Labruyère, E. Newly Visualized Fibrillar Collagen Scaffolds Dictate Entamoeba histolytica Invasion Route in the Human Colon. Cell Microbiol. 2012, 14, 609-621. [CrossRef] [PubMed]

41. Thibeaux, R.; Avé, P.; Bernier, M.; Morcelet, M.; Frileux, P.; Guillén, N.; Labruyère, E. The Parasite Entamoeba histolytica Exploits the Activities of Human Matrix Metalloproteinases to Invade Colonic Tissue. Nat. Commun. 2014, 5, 5142. [CrossRef]

42. Sajid, M.; McKerrow, J.H. Cysteine Proteases of Parasitic Organisms. Mol. Biochem. Parasitol. 2002, 120, 1-21. [CrossRef]

43. Atkinson, H.J.; Babbitt, P.C.; Sajid, M. The Global Cysteine Peptidase Landscape in Parasites. Trends Parasitol. 2009, 25, 573-581. [CrossRef] [PubMed] 
44. Coronado-Velázquez, D.; Betanzos, A.; Serrano-Luna, J.; Shibayama, M. An In Vitro Model of the Blood-Brain Barrier: Naegleria fowleri Affects the Tight Junction Proteins and Activates the Microvascular Endothelial Cells. J. Eukaryot. Microbiol. 2018, 65, 804-819. [CrossRef] [PubMed]

45. Hong, Y.; Kang, J.-M.; Joo, S.-Y.; Song, S.-M.; Lê, H.G.; Thái, T.L.; Lee, J.-Y.; Goo, Y.-K.; Chung, D.-I.; Sohn, W.-M.; et al. Molecular and Biochemical Properties of a Cysteine Protease of Acanthamoeba castellanii. Korean J. Parasitol. 2018, 56, 409-418. [CrossRef] [PubMed]

46. Espinosa, A.; Paz-y-Miño-C, G. Discrimination Experiments in Entamoeba and Evidence from Other Protists Suggest Pathogenic Amebas Cooperate with Kin to Colonize Hosts and Deter Rivals. J. Eukaryot. Microbiol. 2019, 66, 354-368. [CrossRef] [PubMed]

47. Cooper, E.L. From Darwin and Metchnikoff to Burnet and Beyond. Trends Innate Immun. 2008, 15, 1-11. [CrossRef]

48. Dzik, J.M. The Ancestry and Cumulative Evolution of Immune Reactions. Acta Biochim. Pol. 2010, 57, 4. [CrossRef]

49. Simon, M.C.; Kusch, J. Communicative Functions of GPI-Anchored Surface Proteins in Unicellular Eukaryotes. Crit. Rev. Microbiol. 2013, 39, 70-78. [CrossRef]

50. Waddell, D.R.; Duffy, K.T. Breakdown of Self/Nonself Recognition in Cannibalistic Strains of the Predatory Slime Mold, Dictyostelium caveatum. J. Cell Biol. 1986, 102, 298-305. [CrossRef] [PubMed]

51. Benabentos, R.; Hirose, S.; Sucgang, R.; Curk, T.; Katoh, M.; Ostrowski, E.A.; Strassmann, J.E.; Queller, D.C.; Zupan, B.; Shaulsky, G.; et al. Polymorphic Members of the Lag Gene Family Mediate Kin Discrimination in Dictyostelium. Curr. Biol. 2009, 19, 567-572. [CrossRef]

52. Hirose, S.; Benabentos, R.; Ho, H.-I.; Kuspa, A.; Shaulsky, G. Self-Recognition in Social Amoebae Is Mediated by Allelic Pairs of Tiger Genes. Science 2011, 333, 467-470. [CrossRef] [PubMed]

53. Hirose, S.; Chen, G.; Kuspa, A.; Shaulsky, G. The Polymorphic Proteins TgrB1 and TgrC1 Function as a Ligand-Receptor Pair in Dictyostelium Allorecognition. J. Cell Sci. 2017, 208, 975. [CrossRef]

54. Hayakawa, I.S.; Inouye, K. Species Recognition in Social Amoebae. J. Biosci. 2018, 43, 1025-1036. [CrossRef] [PubMed]

55. Espinosa, A.; Paz-Y-Miño-C, G.; Hackey, M.; Rutherford, S. Entamoeba Clone-Recognition Experiments: Morphometrics, Aggregative Behavior, and Cell-Signaling Characterization. J. Eukaryot. Microbiol. 2016, 63, 384-393. [CrossRef] [PubMed]

56. Nakamura, K.; Nakayama, M.; Kawano, M.; Amagai, R.; Ishii, T.; Harigae, H.; Ogasawara, K. Fratricide of Natural Killer Cells Dressed with Tumor-Derived NKG2D Ligand. Proc. Natl. Acad. Sci. USA 2013, 110, 9421-9426. [CrossRef]

57. Miyake, K.; Shiozawa, N.; Nagao, T.; Yoshikawa, S.; Yamanishi, Y.; Karasuyama, H. Trogocytosis of Peptide-MHC Class II Complexes from Dendritic Cells Confers Antigen-Presenting Ability on Basophils. Proc. Natl. Acad. Sci. USA 2017, 114, 1111-1116. [CrossRef]

58. Hamieh, M.; Dobrin, A.; Cabriolu, A.; van der Stegen, S.J.C.; Giavridis, T.; Mansilla-Soto, J.; Eyquem, J.; Zhao, Z.; Whitlock, B.M.; Miele, M.M.; et al. CAR T Cell Trogocytosis and Cooperative Killing Regulate Tumour Antigen Escape. Nature 2019, 568, 112-116. [CrossRef]

59. Miller, H.W.; Suleiman, R.L.; Ralston, K.S. Trogocytosis by Entamoeba histolytica Mediates Acquisition and Display of Human Cell Membrane Proteins and Evasion of Lysis by Human Serum. mBio 2019, 10, e00068-19. [CrossRef] [PubMed]

60. Shao, S.; Sun, X.; Chen, Y.; Zhan, B.; Zhu, X. Complement Evasion: An Effective Strategy That Parasites Utilize to Survive in the Host. Front. Microbiol. 2019, 10, 532. [CrossRef] [PubMed]

61. Kooyman, D.; Byrne, G.; McClellan, S.; Nielsen, D.; Tone, M.; Waldmann, H.; Coffman, T.; McCurry, K.; Platt, J.; Logan, J. In Vivo Transfer of GPI-Linked Complement Restriction Factors from Erythrocytes to the Endothelium. Science 1995, $269,89-92$. [CrossRef]

62. Clayton, A.; Harris, C.L.; Court, J.; Mason, M.D.; Morgan, B.P. Antigen-Presenting Cell Exosomes Are Protected from ComplementMediated Lysis by Expression of CD55 and CD59. Eur. J. Immunol. 2003, 33, 522-531. [CrossRef] [PubMed]

63. Müller, G.A. The Release of Glycosylphosphatidylinositol-Anchored Proteins from the Cell Surface. Arch. Biochem. Biophys. 2018, 656, 1-18. [CrossRef] [PubMed]

64. Dance, A. Core Concept: Cells Nibble One Another via the under-Appreciated Process of Trogocytosis. Proc. Natl. Acad. Sci. USA 2019, 116, 17608-17610. [CrossRef]

65. Kissinger, P. Trichomonas vaginalis: A Review of Epidemiologic, Clinical and Treatment Issues. BMC Infect. Dis. 2015, 15, 307. [CrossRef] [PubMed]

66. Midlej, V.; Benchimol, M. Trichomonas vaginalis Kills and Eats-Evidence for Phagocytic Activity as a Cytopathic Effect. Parasitology 2010, 137, 65-76. [CrossRef] [PubMed]

67. Caterina, P.; Lynch, D.; Ashman, R.B.; Warton, A.; Papadimitriou, J.M. Complement-Mediated Regulation of Trichomonas vaginalis Infection in Mice. Exp. Clin. Immunogenet. 1999, 16, 107-116. [CrossRef] [PubMed]

68. Livson, S.; Jarva, H.; Kalliala, I.; Lokki, A.I.; Heikkinen-Eloranta, J.; Nieminen, P.; Meri, S. Activation of the Complement System in the Lower Genital Tract During Pregnancy and Delivery. Front. Immunol. 2020, 11, 563073. [CrossRef]

69. Ibáñez-Escribano, A.; Nogal-Ruiz, J.J.; Pérez-Serrano, J.; Gómez-Barrio, A.; Escario, J.A.; Alderete, J.F. Sequestration of Host-CD59 as Potential Immune Evasion Strategy of Trichomonas vaginalis. Acta Trop. 2015, 149, 1-7. [CrossRef] [PubMed]

70. Chen, W.; Chen, J.; Zhong, X.; Liang, P.; Lin, W. Ultrastructural and Immunohistochemical Studies on Trichomonas vaginalis Adhering to and Phagocytizing Genitourinary Epithelial Cells. Chin. Med. J. Engl. 2004, 117, 376-381. [PubMed]

71. Benchimol, M. Giardia intestinalis Can Interact, Change Its Shape and Internalize Large Particles and Microorganisms. Parasitology 2021, 148, 500-510. [CrossRef] 
72. Abodeely, M.; DuBois, K.N.; Hehl, A.; Stefanic, S.; Sajid, M.; DeSouza, W.; Attias, M.; Engel, J.C.; Hsieh, I.; Fetter, R.D.; et al. A Contiguous Compartment Functions as Endoplasmic Reticulum and Endosome/Lysosome in Giardia lamblia. Eukaryot. Cell 2009, 8, 1665-1676. [CrossRef] [PubMed]

73. Faubert, G. Immune Response to Giardia duodenalis. Clin. Microbiol. Rev. 2000, 13, 20. [CrossRef] [PubMed]

74. Evans-Osses, I.; Ansa-Addo, E.A.; Inal, J.M.; Ramirez, M.I. Involvement of Lectin Pathway Activation in the Complement Killing of Giardia intestinalis. Biochem. Biophys. Res. Commun. 2010, 395, 382-386. [CrossRef] [PubMed]

75. Rijo-Ferreira, F.; Takahashi, J.S. Sleeping Sickness: A Tale of Two Clocks. Front. Cell Infect. Microbiol. 2020, 10, 525097. [CrossRef]

76. Messenger, L.A.; Miles, M.A.; Bern, C. Between a Bug and a Hard Place: Trypanosoma cruzi Genetic Diversity and the Clinical Outcomes of Chagas Disease. Expert Rev. Anti. Infect. Ther. 2015, 13, 995-1029. [CrossRef] [PubMed]

77. Gramiccia, M.; Gradoni, L. The Current Status of Zoonotic Leishmaniases and Approaches to Disease Control. Int. J. Parasitol. 2005, 35, 1169-1180. [CrossRef] [PubMed]

78. Reithinger, R.; Dujardin, J.-C.; Louzir, H.; Pirmez, C.; Alexander, B.; Brooker, S. Cutaneous Leishmaniasis. Lancet Infect. Dis. 2007, 7, 581-596. [CrossRef]

79. Torres-Guerrero, E.; Quintanilla-Cedillo, M.R.; Ruiz-Esmenjaud, J.; Arenas, R. Leishmaniasis: A Review. Research 2017, 6, 750. [CrossRef] [PubMed]

80. Meyer, H.; de Souza, W. On the Fine Structure of Trypanosoma cruzi in Tissue Cultures of Pigment Epithelium from the Chick Embryo. Uptake of Melanin Granules by the Parasite. J. Protozool. 1973, 20, 590-593. [CrossRef]

81. Pimenta, P.F.; de Souza, W.; Souto-Padrón, T.; da Silva, P.P. The Cell Surface of Trypanosoma cruzi: A Fracture-Flip, Replica-Staining Label-Fracture Survey. Eur. J. Cell Biol. 1989, 50, 263-271. [PubMed]

82. Vidal, J.C.; Alcantara, C.d.L.; de Souza, W.; Cunha-e-Silva, N.L. Loss of the Cytostome-Cytopharynx and Endocytic Ability Are Late Events in Trypanosoma cruzi Metacyclogenesis. J. Struct. Biol. 2016, 196, 319-328. [CrossRef] [PubMed]

83. Steinert, M.; Novikoff, A.B. The Existence of a Cytostome and the Occurrence of Pinocytosis in the Trypanosome, Trypanosoma mega. J. Biophys. Biochem. Cytol. 1960, 8, 563-569. [CrossRef]

84. Preston, T.M. The Form and Function of the Cytostome-Cytopharynx of the Culture Forms of the Elasmobranch Haemoflagellate Trypanosoma raiae Laveran \& Mesnil. J. Protozool. 1969, 16, 320-333. [CrossRef] [PubMed]

85. Milder, R.; Deane, M.P. The Cytostome of Trypanosoma cruzi and T. conorhini. J. Protozool. 1969, 16, 730-737. [CrossRef] [PubMed]

86. Cowman, A.F.; Healer, J.; Marapana, D.; Marsh, K. Malaria: Biology and Disease. Cell 2016, 167, 610-624. [CrossRef] [PubMed]

87. Aikawa, M.; Hepler, P.K.; Huff, C.G.; Sprinz, H. The Feeding Mechanism of Avian Malarial Parasites. J. Cell Biol. 1966, 28 , 355-373. [CrossRef] [PubMed]

88. Coronado, L.M.; Nadovich, C.T.; Spadafora, C. Malarial Hemozoin: From Target to Tool. Biochim. Biophys. Acta 2014, 1840, 2032-2041. [CrossRef]

89. Langreth, S.G.; Jensen, J.B.; Reese, R.T.; Trager, W. Fine Structure of Human Malaria in Vitro. J. Protozool. 1978, $25,443-452$. [CrossRef]

90. Olliaro, P.; Castelli, F.; Milano, F.; Filice, G.; Carosi, G. Ultrastructure of Plasmodium falciparum "in Vitro". I. Base-Line for Drug Effects Evaluation. Microbiologica 1989, 12, 7-14. [PubMed]

91. Lazarus, M.D.; Schneider, T.G.; Taraschi, T.T.T.F. A New Model for Hemoglobin Ingestion and Transport by the Human Malaria Parasite Plasmodium falciparum. J. Cell Sci. 2008, 121, 1937-1949. [CrossRef] [PubMed]

92. Bakar, N.A.; Klonis, N.; Hanssen, E.; Chan, C.; Tilley, L. Digestive-Vacuole Genesis and Endocytic Processes in the Early Intraerythrocytic Stages of Plasmodium falciparum. J. Cell Sci. 2010, 123, 441-450. [CrossRef]

93. McIntosh, M.T.; Vaid, A.; Hosgood, H.D.; Vijay, J.; Bhattacharya, A.; Sahani, M.H.; Baevova, P.; Joiner, K.A.; Sharma, P. Traffic to the Malaria Parasite Food Vacuole. J. Biol. Chem. 2007, 282, 11499-11508. [CrossRef] [PubMed]

94. Elliott, D.A.; McIntosh, M.T.; Hosgood, H.D.; Chen, S.; Zhang, G.; Baevova, P.; Joiner, K.A. Four Distinct Pathways of Hemoglobin Uptake in the Malaria Parasite Plasmodium falciparum. Proc. Natl. Acad. Sci. USA 2008, 105, 2463-2468. [CrossRef]

95. Sudhakar, R.; Das, D.; Thanumalayan, S.; Gorde, S.; Sijwali, P.S. Plasmodium falciparum Atg18 Localizes to the Food Vacuole via Interaction with the Multi-Drug Resistance Protein 1 and Phosphatidylinositol 3-Phosphate. Biochem. J. 2021, 478, 1705-1732. [CrossRef] [PubMed]

96. Montoya, J.G.; Liesenfeld, O. Toxoplasmosis. Lancet 2004, 363, 1965-1976. [CrossRef]

97. Wohlfert, E.A.; Blader, I.J.; Wilson, E.H. Brains and Brawn: Toxoplasma Infections of the Central Nervous System and Skeletal Muscle. Trends Parasitol. 2017, 33, 519-531. [CrossRef] [PubMed]

98. Nichols, B.A.; Chiappino, M.L.; Pavesio, C.E. Endocytosis at the Micropore of Toxoplasma gondii. Parasitol. Res. 1994, 80, 91-98. [CrossRef] [PubMed]

99. Dou, Z.; McGovern, O.L.; Di Cristina, M.; Carruthers, V.B. Toxoplasma gondii Ingests and Digests Host Cytosolic Proteins. mBio 2014, 5, e01188-01114. [CrossRef] [PubMed]

100. Kannan, G.; Thaprawat, P.; Schultz, T.L.; Carruthers, V.B. Acquisition of Host Cytosolic Protein by Toxoplasma gondii Bradyzoites. mSphere 2021, 6, e00934-20. [CrossRef] [PubMed]

101. McGovern, O.L.; Rivera-Cuevas, Y.; Carruthers, V.B. Emerging Mechanisms of Endocytosis in Toxoplasma gondii. Life 2021, 11, 84. [CrossRef] [PubMed] 
102. Romano, J.D.; Sonda, S.; Bergbower, E.; Smith, M.E.; Coppens, I. Toxoplasma gondii Salvages Sphingolipids from the Host Golgi through the Rerouting of Selected Rab Vesicles to the Parasitophorous Vacuole. Mol. Biol. Cell 2013, 24, 1974-1995. [CrossRef] [PubMed]

103. Coppens, I.; Dunn, J.D.; Romano, J.D.; Pypaert, M.; Zhang, H.; Boothroyd, J.C.; Joiner, K.A. Toxoplasma gondii Sequesters Lysosomes from Mammalian Hosts in the Vacuolar Space. Cell 2006, 125, 261-274. [CrossRef] [PubMed]

104. Romano, J.D.; Nolan, S.J.; Porter, C.; Ehrenman, K.; Hartman, E.J.; Hsia, R.-C.; Coppens, I. The Parasite Toxoplasma Sequesters Diverse Rab Host Vesicles within an Intravacuolar Network. J. Cell Biol. 2017, 216, 4235-4254. [CrossRef] [PubMed]

105. Somlata, N.; Nakada-Tsukui, K.; Nozaki, T. AGC Family Kinase 1 Participates in Trogocytosis but Not in Phagocytosis in Entamoeba histolytica. Nat. Commun. 2017, 8, 101. [CrossRef] [PubMed]

106. Saito-Nakano, Y.; Wahyuni, R.; Nakada-Tsukui, K.; Tomii, K.; Nozaki, T. Rab7D Small GTPase Is Involved in Phago-, Trogocytosis and Cytoskeletal Reorganization in the Enteric Protozoan Entamoeba histolytica. Cell Microbiol. 2021, 23, e13267. [CrossRef] [PubMed]

107. Bettadapur, A.; Miller, H.W.; Ralston, K.S. Biting Off What Can Be Chewed: Trogocytosis in Health, Infection, and Disease. Infect. Immun. 2020, 88, e00930-19. [CrossRef]

108. Uribe-Querol, E.; Rosales, C. Phagocytosis: Our Current Understanding of a Universal Biological Process. Front. Immunol. 2020, 11, 1066. [CrossRef] [PubMed]

109. Fu, Y.L.; Harrison, R.E. Microbial Phagocytic Receptors and Their Potential Involvement in Cytokine Induction in Macrophages. Front. Immunol. 2021, 12, 662063. [CrossRef] [PubMed]

110. Penberthy, K.K.; Ravichandran, K.S. Apoptotic Cell Recognition Receptors and Scavenger Receptors. Immunol. Rev. 2016, 269, 44-59. [CrossRef]

111. Nakada-Tsukui, K.; Nozaki, T. Receptors for Phagocytosis and Trogocytosis in Entamoeba histolytica. In Eukaryome Impact on Human Intestine Homeostasis and Mucosal Immunology Overview of the First Eukaryome Congress at Insitut Pasteur Proceedings of the Overview of the First Eukaryome Congress at Insitut Pasteur, Paris, France, 16-18 October 2019, 1st ed.; Springer Nature: Cham, Switzerland, 2020; ISBN 978-3-030-44825-7.

112. Brewer, M.T.; Agbedanu, P.N.; Zamanian, M.; Day, T.A.; Carlson, S.A. Evidence for a Bacterial Lipopolysaccharide-Recognizing G-Protein-Coupled Receptor in the Bacterial Engulfment by Entamoeba histolytica. Eukaryot. Cell 2013, 12, 1433-1438. [CrossRef] [PubMed]

113. Ravdin, J.I.; Guerrant, R.L. Role of Adherence in Cytopathogenic Mechanisms of Entamoeba histolytica. Study with Mammalian Tissue Culture Cells and Human Erythrocytes. J. Clin. Investig. 1981, 68, 1305-1313. [CrossRef]

114. Bracha, R.; Mirelman, D. Adherence and Ingestion of Escherichia coli Serotype 055 by Trophozoites of Entamoeba histolytica. Infect. Immun. 1983, 40, 882-887. [CrossRef] [PubMed]

115. Petri, W.A.; Smith, R.D.; Schlesinger, P.H.; Murphy, C.F.; Ravdin, J.I. Isolation of the Galactose-Binding Lectin That Mediates the in Vitro Adherence of Entamoeba histolytica. J. Clin. Investig. 1987, 80, 1238-1244. [CrossRef] [PubMed]

116. Petri, W.A.; Ravdin, J.I. Cytopathogenicity of Entamoeba histolytica: The Role of Amebic Adherence and Contact-Dependent Cytolysis in Pathogenesis. Eur. J. Epidemiol. 1987, 3, 123-136. [CrossRef] [PubMed]

117. Chadee, K.; Petri, W.A.; Innes, D.J.; Ravdin, J.I. Rat and Human Colonic Mucins Bind to and Inhibit Adherence Lectin of Entamoeba histolytica. J. Clin. Investig. 1987, 80, 1245-1254. [CrossRef] [PubMed]

118. Huston, C.D.; Boettner, D.R.; Miller-Sims, V.; Petri, W.A. Apoptotic Killing and Phagocytosis of Host Cells by the Parasite Entamoeba histolytica. Infect. Immun. 2003, 71, 964-972. [CrossRef]

119. Chadee, K.; Johnson, M.L.; Orozco, E.; Petri, W.A.; Ravdin, J.I. Binding and Internalization of Rat Colonic Mucins by the Galactose/N-Acetyl-n-Galactosamine Adherence Lectin of Entamoeba histolytica. J. Infect. Dis. 1988, 158, 398-406. [CrossRef] [PubMed]

120. Vines, R.R.; Ramakrishnan, G.; Rogers, J.B.; Lockhart, L.A.; Mann, B.J.; Petri, W.A. Regulation of Adherence and Virulence by the Entamoeba histolytica Lectin Cytoplasmic Domain, Which Contains a Beta2 Integrin Motif. Mol. Biol. Cell 1998, 9, $2069-2079$. [CrossRef] [PubMed]

121. Mann, B.J. Structure and Function of the Entamoeba histolytica Gal/GalNAc Lectin. Int. Rev. Cytol. 2002, 216, 59-80. [CrossRef] [PubMed]

122. Hughes, M.A.; Lee, C.W.; Holm, C.F.; Ghosh, S.; Mills, A.; Lockhart, L.A.; Reed, S.L.; Mann, B.J. Identification of Entamoeba histolytica Thiol-Specific Antioxidant as a GalNAc Lectin-Associated Protein. Mol. Biochem. Parasitol. 2003, 127, 113-120. [CrossRef]

123. McCoy, J.J.; Mann, B.J. Proteomic Analysis of Gal/GalNAc Lectin-Associated Proteins in Entamoeba histolytica. Exp. Parasitol. 2005, 110, 220-225. [CrossRef] [PubMed]

124. Somlata, N.; Bhattacharya, S.; Bhattacharya, A. A C2 Domain Protein Kinase Initiates Phagocytosis in the Protozoan Parasite Entamoeba histolytica. Nat. Commun. 2011, 2, 230. [CrossRef]

125. Nakada-Tsukui, K.; Watanabe, N.; Maehama, T.; Nozaki, T. Phosphatidylinositol Kinases and Phosphatases in Entamoeba histolytica. Front. Cell Infect. Microbiol. 2019, 9, 150. [CrossRef] [PubMed]

126. Babuta, M.; Bhattacharya, S.; Bhattacharya, A. Entamoeba histolytica and Pathogenesis: A Calcium Connection. PLoS Pathog. 2020, 16, e1008214. [CrossRef] 
127. Ghosh, S.K.; Samuelson, J. Involvement of P21racA, Phosphoinositide 3-Kinase, and Vacuolar ATPase in Phagocytosis of Bacteria and Erythrocytes by Entamoeba histolytica: Suggestive Evidence for Coincidental Evolution of Amebic Invasiveness. Infect. Immun. 1997, 65, 4243-4249. [CrossRef] [PubMed]

128. Raha, S.; Dalal, B.; Biswas, S.; Biswas, B.B. Myo-Inositol Trisphosphate-Mediated Calcium Release from Internal Stores of Entamoeba histolytica. Mol. Biochem. Parasitol. 1994, 65, 63-71. [CrossRef]

129. Giri, B.; Raha, S.; Bhattacharyya, B.; Biswas, S.; Biswas, B.B. Relative Importance of Inositol $(1,4,5)$ Trisphosphate and Inositol $(1,3,4,5)$ Tetrakisphosphate in Entamoeba histolytica. FEBS Lett. 1996, 393, 109-112. [CrossRef]

130. Van Dijken, P.; de Haas, J.R.; Craxton, A.; Erneux, C.; Shears, S.B.; Van Haastert, P.J. A Novel, Phospholipase C-Independent Pathway of Inositol 1,4,5-Trisphosphate Formation in Dictyostelium and Rat Liver. J. Biol. Chem. 1995, 270, 29724-29731. [CrossRef] [PubMed]

131. Prole, D.L.; Taylor, C.W. Identification of Intracellular and Plasma Membrane Calcium Channel Homologues in Pathogenic Parasites. PLoS ONE 2011, 6, e26218. [CrossRef]

132. Hashimoto, M.; Enomoto, M.; Morales, J.; Kurebayashi, N.; Sakurai, T.; Hashimoto, T.; Nara, T.; Mikoshiba, K. Inositol 1,4,5Trisphosphate Receptor Regulates Replication, Differentiation, Infectivity and Virulence of the Parasitic Protist Trypanosoma cruzi. Mol. Microbiol. 2013, 87, 1133-1150. [CrossRef]

133. Dijken, P.V.; Bergsma, J.C.T.; Haastert, P.J.M.V. Phospholipase-C-Independent Inositol 1,4,5-Trisphosphate Formation in Dictyostelium Cells-Activation of a Plasma-Membrane-Bound Phosphatase by Receptor-Stimulated Ca2+ Influx. Eur. J. Biochem. 1997, 244, 113-119. [CrossRef] [PubMed]

134. Mansuri, M.S.; Babuta, M.; Ali, M.S.; Bharadwaj, R.; Deep, J.G.; Gourinath, S.; Bhattacharya, S.; Bhattacharya, A. Autophosphorylation at Thr279 of Entamoeba histolytica Atypical Kinase EhAK1 Is Required for Activity and Regulation of Erythrophagocytosis. Sci. Rep. 2016, 6, 16969. [CrossRef] [PubMed]

135. Somlata, J.; Bhradwaj, R.; Nozaki, T. PtdIns(3,4,5)P3 Binding Protein Screening Reveals Unique Molecules Involved in Endocytic Processes, 1st ed.; Guillen, N., Ed.; Springer International Publishing: Cham, Switzerland, 2020; ISBN 978-3-030-44825-7.

136. Pearce, L.R.; Komander, D.; Alessi, D.R. The Nuts and Bolts of AGC Protein Kinases. Nat. Rev. Mol. Cell Biol. 2010, 11, 9-22. [CrossRef] [PubMed]

137. Anamika, K.; Bhattacharya, A.; Srinivasan, N. Analysis of the Protein Kinome of Entamoeba histolytica. Proteins 2008, 71, 995-1006. [CrossRef]

138. Kawano-Sugaya, T.; Izumiyama, S.; Yanagawa, Y.; Saito-Nakano, Y.; Watanabe, K.; Kobayashi, S.; Nakada-Tsukui, K.; Nozaki, T. Near-Chromosome Level Genome Assembly Reveals Ploidy Diversity and Plasticity in the Intestinal Protozoan Parasite Entamoeba histolytica. BMC Gennomics 2020, 21, 813. [CrossRef]

139. Jaffe, A.B.; Hall, A. Rho Gtpases: Biochemistry and Biology. Annu. Rev. Cell Dev. Biol. 2005, 21, 247-269. [CrossRef] [PubMed]

140. Rottner, K.; Stradal, T.E. Actin Dynamics and Turnover in Cell Motility. Curr. Opin. Cell Biol. 2011, 23, 569-578. [CrossRef] [PubMed]

141. Gerlach, B.D.; Marinello, M.; Heinz, J.; Rymut, N.; Sansbury, B.E.; Riley, C.O.; Sadhu, S.; Hosseini, Z.; Kojima, Y.; Tang, D.D.; et al. Resolvin D1 Promotes the Targeting and Clearance of Necroptotic Cells. Cell Death Differ. 2020, 27, 525-539. [CrossRef]

142. Guillén, N.; Boquet, P.; Sansonetti, P. The Small GTP-Binding Protein RacG Regulates Uroid Formation in the Protozoan Parasite Entamoeba histolytica. J. Cell Sci. 1998, 111 Pt. 12, 1729-1739. [CrossRef]

143. Bharadwaj, R.; Arya, R.; Shahid, M.M.; Bhattacharya, S.; Bhattacharya, A. EhRho1 Regulates Plasma Membrane Blebbing through PI3 Kinase in Entamoeba histolytica. Cell Microbiol. 2017, 19, 2751. [CrossRef] [PubMed]

144. Bharadwaj, R.; Sharma, S.; Janhawi, J.; Arya, R.; Bhattacharya, S.; Bhattacharya, A. EhRho1 Regulates Phagocytosis by Modulating Actin Dynamics through EhFormin1 and EhProfilin1 in Entamoeba histolytica. Cell Microbiol. 2018, 20, e12851. [CrossRef] [PubMed]

145. Abdu, Y.; Maniscalco, C.; Heddleston, J.M.; Chew, T.-L.; Nance, J. Developmentally Programmed Germ Cell Remodelling by Endodermal Cell Cannibalism. Nat. Cell Biol. 2016, 18, 1302-1310. [CrossRef] [PubMed]

146. Makiuchi, T.; Santos, H.J.; Tachibana, H.; Nozaki, T. Hetero-Oligomer of Dynamin-Related Proteins Participates in the Fission of Highly Divergent Mitochondria from Entamoeba histolytica. Sci. Rep. 2017, 7, 13439. [CrossRef]

147. Swanson, J.A.; Johnson, M.T.; Beningo, K.; Post, P.; Mooseker, M.; Araki, N. A Contractile Activity That Closes Phagosomes in Macrophages. J. Cell Sci. 1999, 112 Pt. 3, 307-316. [CrossRef]

148. Aslam, S.; Bhattacharya, S.; Bhattacharya, A. The Calmodulin-like Calcium Binding Protein EhCaBP3 of Entamoeba histolytica Regulates Phagocytosis and Is Involved in Actin Dynamics. PLoS Pathog. 2012, 8, e1003055. [CrossRef]

149. Nakada-Tsukui, K.; Saito-Nakano, Y.; Ali, V.; Nozaki, T. A Retromerlike Complex Is a Novel Rab7 Effector That Is Involved in the Transport of the Virulence Factor Cysteine Protease in the Enteric Protozoan Parasite Entamoeba histolytica. Mol. Biol. Cell 2005, 16, 5294-5303. [CrossRef] [PubMed]

150. Nakada-Tsukui, K.; Okada, H.; Mitra, B.N.; Nozaki, T. Phosphatidylinositol-Phosphates Mediate Cytoskeletal Reorganization during Phagocytosis via a Unique Modular Protein Consisting of RhoGEF/DH and FYVE Domains in the Parasitic Protozoon Entamoeba histolytica. Cell Microbiol. 2009, 11, 1471-1491. [CrossRef] [PubMed]

151. Furukawa, A.; Nakada-Tsukui, K.; Nozaki, T. Novel Transmembrane Receptor Involved in Phagosome Transport of Lysozymes and $\beta$-Hexosaminidase in the Enteric Protozoan Entamoeba histolytica. PLoS Pathog. 2012, 8, e1002539. [CrossRef]

152. Nakada-Tsukui, K.; Tsuboi, K.; Furukawa, A.; Yamada, Y.; Nozaki, T. A Novel Class of Cysteine Protease Receptors That Mediate Lysosomal Transport. Cell Microbiol. 2012, 14, 1299-1317. [CrossRef] 
153. Furukawa, A.; Nakada-Tsukui, K.; Nozaki, T. Cysteine Protease-Binding Protein Family 6 Mediates the Trafficking of Amylases to Phagosomes in the Enteric Protozoan Entamoeba histolytica. Infect. Immun. 2013, 81, 1820-1829. [CrossRef] [PubMed]

154. Marumo, K.; Nakada-Tsukui, K.; Tomii, K.; Nozaki, T. Ligand Heterogeneity of the Cysteine Protease Binding Protein Family in the Parasitic Protist Entamoeba histolytica. Int. J. Parasitol. 2014, 44, 625-635. [CrossRef] [PubMed]

155. Yutin, N.; Wolf, M.Y.; Wolf, Y.I.; Koonin, E.V. The Origins of Phagocytosis and Eukaryogenesis. Biol. Direct 2009, 4, 9. [CrossRef] [PubMed] 